\title{
Gaya Belajar dan Nilai Kalkulus Diferensial: Apakah Mempengaruhi IPK?
}

\author{
Entit Puspita ${ }^{1}$, Dadang Juandi ${ }^{2}$, Rizky Rosjanuardi ${ }^{3}$ \\ ${ }^{1}$ Progran Studi Matematika, Universitas Pendidikan Indonesia, Bandung, Indonesia; \\ ${ }^{1 *}$ entitpuspita@upi.edu; ${ }^{2}$ dadang.juandi@upi.edu; ${ }^{3}$ rizky@upi.edu
}

Info Artikel: Dikirim: 17 Juni 2020; Direvisi: 11 September 2020; Diterima: 21 September 2020 Cara sitasi: Puspita, E., Juandi, D., \& Rosjanuardi, R. (2020). Gaya Belajar dan Nilai Kalkulus Diferensial: Apakah Mempengaruhi IPK?. JNPM (Jurnal Nasional Pendidikan Matematika), 4(2), 324-337.

\begin{abstract}
Abstrak. Tujuan penelitian ini adalah untuk mengkaji pengaruh gaya belajar dan capaian kalkulus diferensial terhadap Indeks Prestasi Komulatif (IPK) mahasiswa calon guru matematika, baik secara parsial maupun secara simultan. Berbagai penelitian membuktikan adanya korelasi gaya belajar dengan capaian pembelajaran, ditemukan pula bukti permasalahan dalam penguasaan konsep kalkulus diferensial. Penelitian terkait hubungan gaya belajar dan capaian kalkulus diferensial terhadap IPK mahasiswa calon guru matematika penting dilakukan, mengingat pada gilirannya mereka akan menjadi ujung tombak keberhasilan sebuah proses pembelajaran. Metode kuantitatif dengan desain deskriptif korelasional dan teknik pengumpulan data survey cross-sectional dipilih. Sampel sebanyak 119 mahasiswa yang mengambil mata kuliah kalkulus diferensial. Data yang diperoleh berupa gaya belajar, nilai, dan IPK. Analisis data dilakukan dengan menggunakan Ancova. Hasil penelitian menunjukkan bahwa perbedaan gaya belajar dan capaian kalkulus diferensial memiliki pengaruh terhadap IPK mahasiswa calon guru matematika, secara simultan gaya belajar dan capaian Kalkulus Differensial memiliki pengaruh sebesar 55,7\% terhadap IPK mahasiswa dan secara parsial didominasi oleh capaian kalkulus diferensial. Hasil ini mengindikasikan pentingnya memperhatikan gaya belajar mahasiswa dan dapat dijadikan rambu-rambu dalam merancang sebuah disain perkuliahan kalkulus diferensial disesuaikan dengan keunikan gaya belajarnya, mengingat pengaruhnya terhadap IPK mahasiswa cukup besar.
\end{abstract}

Kata Kunci: Gaya Belajar, Capaian Pembelajaran, Indeks Prestasi Kumulatif.

\begin{abstract}
The purpose of this study was to examine the effect of learning styles and achievement of differential calculus on the Cumulative Achievement Index (GPA) of students as mathematics teacher candidates, either partially or simultaneously. Various studies have shown that there is a correlation between learning styles and learning outcomes. There is also evidence of problems in mastering the concept of differential calculus. Research related to the relationship between learning styles and the achievement of differential calculus on students' GPA as mathematics teacher candidates is important, considering that, in turn, they will spearhead the success of
\end{abstract}


a learning process. Quantitative methods with correlational descriptive design and cross-sectional survey data collection techniques were selected. A sample of 119 students took the differential calculus course. The data obtained were in the form of learning styles, grades, and GPA. Data analysis was performed using ANCOVA (Analysis of Covariance). The results showed that differences in learning styles and achievement of differential calculus influenced students' GPA as mathematics teacher candidates, simultaneously learning styles, and the achievement of Differential Calculus had an effect of $55.7 \%$ on student GPA and partially dominated by the achievement of differential calculus. These results indicate the importance of paying attention to student learning styles and can be used as signposts in designing a differential calculus lecture design tailored to the uniqueness of their learning styles, considering that they have a large enough impact on student GPA.

Keywords: Learning Style, Learning Achievement, Grade Point Average.

\section{Pendahuluan}

Setiap individu adalah unik dan berbeda dari individu lainnya (Morgan, 1995), sehingga gaya belajarpun akan berbeda sesuai dengan preferensi pribadi tentang cara belajar. Pendidikan adalah suatu proses terhadap orangorang berbeda, namun sistem pendidikan sering mengabaikan kondisi ini, sehingga membatasi guru dan peserta didik untuk menggunakan model pembelajaran tertentu (Morgan, 1995). Kolb (1984), mengatakan bahwa lingkungan belajar dan materi yang dikembangkan akan memiliki dampak yang berbeda pada setiap siswa dikarenakan perbedaan gaya belajar. Sejalan dengan pendapat tersebut, Aslaken \& Loras (2019) mengatakaan bahwa individu dengan gaya belajar dan jenis hambatan belajar (learning obstacle) yang berbeda diperkirakan akan memiliki hasil pembelajaran yang lebih baik jika proses pembelajaran disesuaikan dengan gaya belajar dan learning obstacle mereka.

Setiap manusia diciptakan berbeda dalam segala hal, termasuk diantaranya cara dalam mendapatkan pengetahuan. Cara seseorang menyerap, mengatur, dan mengolah informasi untuk mendapatkan pengetahuan dikenal dengan gaya belajar (DePorter \& Hernacki, 2007). Sementara, definisi gaya belajar menurut Pritchard (2009), yaitu: (a) cara tertentu di mana seorang individu belajar; modus pembelajaran - pilihan individu atau cara terbaik untuk berpikir, memproses informasi dan menunjukkan pembelajaran; (b) cara yang disukai individu untuk memperoleh pengetahuan dan keterampilan; atau (c) kebiasaan, strategi, atau perilaku mental reguler tentang belajar, khususnya yang disengaja, yang ditampilkan seorang individu. Karena keunikannya, siswa yang berada di sekolah atau bahkan duduk di kelas yang sama pada umumnya memiliki gaya belajar yang berbeda, begitu juga kemampuan siswa dalam memahami dan menyerap pelajaran sudah pasti 
berbeda tingkatnya. Ada siswa yang memahami dan menyerap informasi dengan cepat, sedang dan ada pula yang lambat. Guru perlu mengenali gaya belajar yang dimiliki siswa sehingga mereka dapat menggunakan cara termudah dalam menyerap informasi.

Dari uraian pada bagian sebelumnya dapat di disimpulkan bahwa gaya belajar adalah cara yang disukai seseorang untuk belajar; misalnya lebih menyukai penggunaan gambar daripada teks; lebih menyukai bekerja secara berkelompok daripada bekerja sendiri; atau lebih menyukai belajar secara terstruktur daripada cara yang tidak terstruktur. Preferensi belajar mengacu pada pilihan pendekatan intelektual seseorang untuk belajar, yang berpengaruh terhadap bagaimana pembelajaran berlangsung untuk individu tersebut, hal ini perlu menjadi pertimbangan terkait dengan apa yang diharapkan guru dari peserta didik di kelas (Pritchard, 2009).

Pengkategorian modalitas (type) gaya belajar yang dikemukakan para ahli bisa berdasarkan preferensi kognitif, profil kecerdasan, dan preferensi sensori. Pada Penelitian ini modalitas (type) gaya belajar akan didasarkan pada preferensi sensori atau kemampuan yang dimiliki otak dalam menyerap, mengelola dan menyampaikan informasi, ada tiga tipe gaya belajar, yaitu gaya belajar visual, gaya belajar auditorial, dan gaya belajar kinestetik (DePorter \& Hernacki, 2007; Gholami \& Bagheri, 2013). Berdasarkan preferensi sensori tersebut, siswa visual akan belajar melalui sesuatu yang mereka lihat, siswa auditorial akan belajar dengan cara mendengar, dan siswa kinestetik akan belajar dengan gerak, bekerja, dan menyentuh. Sejalan dengan pendapat Deporter, Pritchard (2009) memberikan ciri dari ketiga gaya belajar yaitu: (a) gaya belajar visual, pembelajar yang lebih suka belajar dengan melihat; (b) gaya belajar auditorial, pembelajar yang lebih suka belajar dengan mendengarkan; (c) gaya belajar kinestetik, pembelajar yang lebih suka belajar dengan melakukan.

Setiap orang dapat belajar dengan menggunakan ketiga modalitas (visual, auditorial, dan kinestetik), tetapi pada umumnya seseorang lebih cenderung pada salah satu dari ketiganya. Mengetahui gaya belajar yang berbeda dapat membatu guru memperkuat hubungan dengan peserta didiknya (DePorter \& Hernacki, 2007).

Hasil penelitian memberikan bukti bahwa terdapat korelasi antara gaya belajar dengan kemampuan pemecahan masalah, seperti penelitian yang dilakukan Gholani \& Bagheri (2013). Sementara, Magdalena (2015), dan Bosman \& Schulze (2018), dalam penelitiannya menyimpulkan terdapat 
korelasi positif antara gaya belajar dengan kinerja akademik siswa. Di samping itu ditemukan bukti bahwa gaya pembelajaran yang disesuaikan dengan modalitas gaya belajar siswa dapat meningkatkan kemampuan belajar mereka, misalkan dalam penelitian Rourke, Ahmad, Collins \& Warriner (2002), Constantinidou \& Baker (2002), dan Faculty (2016). Sirmaci (2010) mengemukakan terdapat hubungan positif yang signifikan antara sikap siswa terhadap matematika dan gaya belajar mereka. Di samping itu, guru yang lebih teliti memahami perbedaan dalam gaya belajar individu, akan membuka peluang mereka untuk memenuhi beragam kebutuhan belajar peserta didik (Goulding \& Syed-Khuzzan, 2014).

Magdalena (2015) mempercayai bahwa kinerja akademik dipengaruhi juga oleh faktor-faktor lain seperti faktor kepribadian, faktor kognitif, faktor motivasi-emosional. Sejalan dengan Magdalena, Sabri, Safee, \& Wan Afthanorhan (2014) dalam penelitiannya merekomendasikan bahwa seorang guru harus berusaha untuk mengidentifikasi gaya-gaya belajar siswa ketika siswa terlihat mengalami hambatan dalam belajar sehingga dapat memberikan rekomendasi bagaimana siswa dapat mengatasi permasalahannya. Beberapa rekomendasi diberikan kepada guru dalam meningkatkan kinerja akademik siswa, antara lain: menciptakan lingkungan belajar yang baik, menggunakan metoda pengajaran yang mengakomodasi berbagai gaya belajar, serta menunjukkan gaya kepemimpinan (Yildirim, Acar, Bull, \& Sevinc, 2008; Bosman \& Schulze, 2018; dan Altun \& Serin 2019). Dengan demikian dapat dikatakan bahwa guru berkontribusi besar bagi keberhasilan siswa, dilakukan dengan menunjukkan rasa simpatinya terhadap mereka. Lingkungan yang dapat diciptakan guru misalnya, menggunakan media pembelajaran audio visual; memberi kesempatan kepada siswa untuk berdiskusi dan mengemukakan pendapat, menuliskan laporan tertulis, dan lainnya. Dengan kata lain, guru yang hanya fokus pada materi ajar dan bukan pada siswa, menjaga jarak dengan siswa, tidak berperan aktif dalam menunjang keberhasilan siswa.

Penerapan konsep gaya belajar lazim diterapkan di tingkat perguruan tinggi (Newton \& Miah, 2017), selanjutnya (Dandy \& Bendersky, 2014) menyimpulkan hasil survey terhadap staf pengajar perguruan tinggi di AS yang mengatakan bahwa dua pertiga dari mereka mengatakan bahwa mengajar yang disesuaikan dengan gaya belajar mahasiswa dapat meningkatkan hasil pembelajaran. Penelitian yang telah dilakukan hanya memperhatikan gaya belajar, tanpa mempertimbangkan hambatan belajar (learning obstacle) yang di alami individu dengan gaya belajar tertentu. Karena individu dengan gaya belajar tertentu, akan memiliki hambatan belajar yang 
berbeda, mengingat keunikan dari masing-masing individu. Penelitian akan difokuskan kepada mahasiswa calon guru matematika, yang karena keunikannya memiliki gaya belajar dan learning obstacle yang berbeda, mengingat nantinya mereka harus dapat mengenali learning obstacle peserta didiknya, dan akan menjadi ujung tombak keberhasilan sebuah proses pendidikan.

Perkuliahan pada program studi penghasil calon guru merupakan suatu proses yang kompleks dan berkesinambungan, di dalamnya melibatkan proses interaksi antara mahasiswa calon guru, dosen, dan mata kuliah itu sendiri. Namun pada prakteknya, proses perkuliahan tidak selalu berjalan seperti yang diharapkan. Tingkat kemampuan mahasiswa yang beragam, gaya belajar mahasiswa, serta kreativitas dosen dalam merancang perkuliahan menjadi hal yang perlu diperhatikan dalam pencapaian tujuan perkuliahan. Perkuliahan yang efektif salah satunya ditandai dengan keberhasilan mahasiswa dalam belajar. Pertimbangan-pertimbangan tentang bagaimana mahasiswa belajar merupakan langkah awal yang perlu diperhatikan dosen, dengan tujuan memudahkan dalam pencapaian tujuan perkuliahan yang telah ditetapkan.

Dosen memiliki peran penting dalam membantu dan membimbing mahasiswa calon guru (matematika) dalam memahami suatu pengetahuan. Dosen dituntut untuk menciptakan suatu situasi perkuliahan yang kondusif dan efektif. Berdasarkan hal tersebut, penting bagi dosen untuk memiliki kemampuan menyusun rancangan perkuliahan disesuaikan dengan tingkat kemampuan dan gaya belajar mahasiswa, sehingga mahasiswa dapat mengembangkan potensi yang mereka miliki.

Penelitian terkait konsep kalkulus telah banyak dilakukan, dan menyimpulkan bahwa: umumnya turunan tidak difahami secara konseptual oleh siswa; siswa memiliki kesalahan mendasar dalam konsep turunan, limit, dan konsep tak hingga (Orton, 1983; Kim, Kang, \& Lee, 2015; Wahyuni, 2017 ). Sejalan dengan itu, Orhun (2012) menyatakan bahwa ditemukan perbedaan signifikan antara gaya belajar mahasiswa teknik dan kinerja mereka pada mata kuliah kalkulus. Penelitian - penelitian tersebut memberikan informasi, bahwa masih ditemukan berbagai masalah pada perkuliahan kalkulus diferensial pada mahasiswa jurusan matematika. Ditemukan juga bukti, bahwa mahasiswa teknik pun masih mengalami masalah pada mata kuliah kalkulus, dimana mata kuliah tersebut merupakan mata kuliah yang umumnya diberikan di tingkat awal dan menjadi dasar mata kuliah lainnnya. 
Mata kuliah kalkulus diferensial adalah mata kuliah wajib pada Program Studi Pendidikan Matematika sebagai penghasil calon guru dan menjadi prasyarat untuk beberapa mata kuliah yang lain, sehingga posisinya dalam kurikulum menjadi penting. Penelitian terkait permasalahan pada kalkulus baik terhadap siswa maupun mahasiswa, maupun penelitian yang mengaitkan gaya belajar dengan hasil belajar telah dilakukan. Pada penelitian ini dilakukan suatu kajian yang melihat keterkaitan antara gaya belajar mahasiswa calon guru matematika dengan capaian mata kuliah tersebut, umumnya terhadap Indeks Prestasi secara keseluruhan. Penelitian ini perlu dilakukan mengingat calon guru matematika akan menjadi ujung tombak keberhasilan suatu proses pembelajaran. Mengenali keterkaitan gaya belajar calon guru dengan hasil belajar akan memberi informasi kepada para dosen dalam merancang sebuah disain perkuliahan yang dapat memberikan pelayanan terbaik kepada mahasiswa. Jika ini terbukti maka berbagai disain perkuliahan dapat disiapkan dosen disesuaikan dengan perbedaan gaya belajar masing-masing mahasiswa supaya para mahasiswa dapat mengembangkan potensi yang dimilikinya secara optimal.

Berdasarkan uraian di atas, terkait dengan masih ditemukannya permasalahan pada mata kuliah kalkulus diferensial, ditemukan berbagai bukti korelasi antar gaya belajar dengan capain pembelajaran, dan mahasiswa calon guru matematika dengan gaya belajar tertentu karena keunikannya juga akan memiliki learning obstacle yang berbeda, maka tujuan dari penelitian ini adalah mengkaji pengaruh gaya belajar dan covariate capaian mata kuliah (MK) Kalkulus Diferensial mahasiswa calon guru matematika terhadap IPK mahasiswa, untuk selanjutnya dilihat seberapa besar pengaruh dari masing-masing varaibel bebas dan covariate terhadap varibel terikat baik secara parsial maupun secara simultan.

\section{Metode}

Populasi pada penelitian ini adalah seluruh mahasiswa pada Program Studi Pendidikan Matematika FPMIPA UPI, dengan sampel mahasiswa yang telah mengambil mata kuliah Kalkulus Diferensial berjumlah 119 orang. Sampel tersebut cukup representatif karena tersebar dari semua angkatan, sehingga dapat merepresentasikan karakteristik populasinya.

Metode yang digunakan dalam penelitian ini adalah metode kuantitatif dengan desain deskriptif korelasional dan teknik pengumpulan datanya adalah survey. Teknik survey dipilih karena peneliti memerlukan data yang digunakan untuk menjawab permasalahan penelitian, tanpa memberi perlakuan terhadap sampel. Data yang dimaksud adalah tipe gaya belajar, 
nilai MK Kalkulus diferensial, dan IPK mahasiswa. Tipe survei yang digunakan adalah survei cross-sectional, dimana peneliti mengumpulkan informasi dari sampel pada suatu waktu yang telah ditentukan.

Data terkait preverensi gaya belajar akan dijaring dengan menggunakan angket dalam bentuk Skala Likert, dengan item-item pertanyaan/ pernyataannya disusun berdasarkan teori dan ciri-ciri gaya belajar menurut Deporter \& Hernacky (2007), kisi-kisi angket disajikan pada Tabel 1.

Tabel 1. Kisi-Kisi Angket Gaya Belajar

\begin{tabular}{lll}
\hline Gaya Belajar & Indikator & No. Pernyataan \\
\hline & Belajar dengan cara visual & 1,5 \\
Gaya Belajar & Mengerti baik mengenai posisi, bentuk, & 5 \\
Visual & angka, dan warna & $2,8,10$ \\
& Rapi dan teratur & $4,6,12,14$ \\
& Tidak Terganggu dengan keributan & 7,11 \\
& Sulit menerima intruksi verbal & $9,16,18$ \\
& Belajar dengan cara mendengar & $3,13,17,20$ \\
Gaya Belajar & Baik dalam aktivitas lisan & \\
Auditory & Memiliki kepekaan terhadap music & $21,22,24$ \\
& Mudah terganggu dengan keributan & 29 \\
& Lemah dalam aktivitas visual & 15,23 \\
& Belajar dengan aktivitas fisik & $19,25,27,31,32,34$ \\
Gaya Belajar & Peka terhadap ekspresi dan bahasa tubuh & $28,35,36$ \\
Kinestetik & Berorientasi pada fisik dan banyak bergerak & $30,33,39$ \\
& Suka coba-coba dan kurang rapi & 38,41 \\
& Lemah dalam aktivitas verbal & 37,40 \\
\hline
\end{tabular}

Sebelum angket tersebut digunakan dilakukan konsultasi dengan tim ahli dari UPT BK UPI (Unit Pelayanan Teknis Bimbingan dan Konseling UPI), untuk menjamin validitas isi angket tersebut. Setelah dilakukan revisi berdasarkan masukan dari dua tim ahli, angket disebarkan kepada populasi dalam bentuk googleform. Terdapat dua tipe pertanyaan dalam angket yaitu pertanyaan terbuka disajikan di bagian awal sedangkan pertanyaan tertutup di mana responden tinggal memilih item yang telah disediaan peneliti disajikan pada bagian akhir. Berdasarkan data yang diperoleh dari angket gaya belajar, setiap orang akan dikelompokkan ke dalam modalitas gaya belajar tertentu berdasarkan skor tertinggi dari ketiga modalitas yang ada. Sehingga seorang mahasiswa calon guru matematika dapat dikategorikan apakah Visual (V), Auditori (A), atau Kinestetik). 
Analisis data dilakukan dengan menggunakan Ancova (Analysis of Covariance), dengan pertimbangan data variabel terikat berupa data berskala rasio (data IPK mahasiswa), sedangkan varibel bebas merupakan gabungan dari data berskala nominal (untuk data gaya belajar) dan skala rasio (untuk data covariate (capaian mata kuliah Kalkulus Diferensial) (Montgomery, 2012). Dalam penelitian ini, capaian mata kuliah Kalkulus Diferensial dinyatakan dengan nilai mata kuliah, karena didalamnya memuat komponen-komponen yang menggambarkan kemampuan yang diperoleh mahasiswa melalui internalisasi pengetahuan, keterampilan, dan sikap. Pengujian hipotesis berkaitan dengan hubungan antara gaya belajar, capaian nilai MK Kalkulus Diferensial dan IPK mahasiswa terdiri atas: 1) hipotesis 1: terdapat pengaruh perbedaan gaya belajar terhadap IPK mahasiswa calon guru matematika; 2) hipotesis 2: terdapat pengaruh perbedaan gaya belajar dan capaian MK Kalkulus Diferensial secara simultan terhadap IPK mahasiswa calon guru matematika.

\section{Hasil dan Pembahasan}

Berdasarkan data angket gaya belajar, yang disebarkan kepada mahasiswa calon guru matematika pada Program Studi Pendidikan Matematika FPMIPA UPI dan diisi oleh 119 orang sampel, diperoleh hasil rata-rata IPK dan modalitas (kecenderungan) gaya belajar mahasiswa calon guru matematika seperti disajikan pada Tabel 2 berikut:

Tabel 2. Rata-Rata Capaian MK Kalkulus Diferensial, IPK dan Modalitas Gaya Belajar Mahasiswa Calon Guru Matematika

\begin{tabular}{lllll}
\hline Gaya Belajar & $\begin{array}{l}\text { Kalkulus } \\
\text { Diferensial }\end{array}$ & IPK & Jumlah & Persentase \\
\hline Visual & 79,50 & 3,4759 & 17 & 14,28 \\
Auditorial & 76,47 & 3,4579 & 66 & 55,46 \\
Kinestetik & 75,31 & 3,3036 & 36 & 30,25 \\
\hline Jumlah Total & 76.38 & 3,4138 & 119 & 100 \\
\hline
\end{tabular}

Tabel 2 menunjukkan bahwa: (a) terdapat perbedaan rata-rata capaian MK Kalkulus Diferensial dan rata-rata terbesar dicapai oleh mahasiswa dengan gaya belajar visual, (b) rata-rata IPK mahasiswa calon guru matematika pada ketiga gaya belajar tidak terlalu jauh berbeda akan tetapi rata-rata IPK mahasiswa dengan gaya belajar visual sedikit lebih tinggi dari dua gaya belajar lainnya, (b) pada umumnya mahasiswa calon guru matematika memiliki modalitas (kecenderungan) gaya belajar auditorial, ini menandakan bahwa mereka pada umumnya belajar dengan cara mendengar, unggul dalam aktivitas lisan tetapi lemah dalam aktivitas visual, peka terhadap musik tetapi mudah terganggu dengan keributan. Walaupun mayoritas mahasiswa 
memiliki modalitas gaya belajar auditorial, tidak berarti harus mengabaikan dua gaya belajar yang lain, karena mereka juga memiliki karakteristik gaya belajar visual dan kinestetik walaupun tidak dominan.

Dari data yang disajikan pada Tabel 2 terlihat bahwa, baik rata-rata capaian MK Kalkulus Diferensial maupun IPK mahasiswa, ketiga gaya belajar tidak menunjukkan perbedaan yang cukup besar walaupun gaya belajar visual memiliki nilai rata-rata yang sedikit lebih tinggi dari dua gaya belajar lainnya. Hasil ini sejalan dengan penelitian Tonra, Budiarto, \& Masriyah (ㅁ19), yang menyimpulkan bahwa dari tiga aspek HOTS yang diteliti, pada aspek menganalisis dan mencipta siswa dengan gaya belajar kinestetik dan visual memberikan hasil yang sama baiknya, sedangkan pada aspek mengevaluasi siswa dengan gaya belajar kinestetik dapat menggunakan strategi dalam memeriksa kebenaran dalam jawaban tetapi siswa dengan gaya belajar visual tidak menggunakan strategi.

Variabel terikat dalam penelitian ini adalah Indeks Prestasi Kumulatif (IPK) mahasiswa calon guru matematika, sedangkan variabel bebasnya adalah tipe gaya belajar. Dalam kenyataannya terdapat faktor-faktor lain yang juga mempengaruhi IPK mahasiswa, dalam penelitian ini diamati capaian MK Kalkulus Diferensial dengan pertimbangan MK Kalkulus Diferensial merupakan mata kuliah wajib dan menjadi prasyarat untuk banyak mata kuliah yang lain. Oleh karena itu capaian MK Kalkulus Diferensial digunakan sebagai variabel kontrol (covariate).

Dengan bantuan SPSS akan dilakukan Teknik Ancova untuk mengetahui pengaruh varibel bebas berupa perbedaan tipe gaya belajar terhadap variabel terikat berupa IPK mahasiswa calon guru matematika, selanjutnya akan dilihat juga pengaruh dari covariate capaian MK Kalkulus Diferensial terhadap IPK. Di samping itu akan dilihat juga berapa besar pengaruh dari variabel bebas dan covariate terhadap variabel terikat, baik secara parsial maupun secara simultan.

Dalam Ancova, harus dipenuhi syarat terdapat hubungan linier antara covariate dan variabel terikatnya. Oleh Karena itu akan diperiksa apakah terdapat hubungan linier antara covariate nilai MK Kalkulus Diferensial dengan variabel terikat IPK mahasiswa dengan terlebih dahulu menghilangkan pengaruh perlakukan. Jika terbukti terdapat hubungan linier baru akan dilihat pengaruh dari variabel bebas terhadap variabel terikat. Berdasarkan hal tersebut tipe Ancova yang dipilih adalah tipe III, tanpa 
didasari asumsi apapun, apakah covariate nilai MK Kalkulus Diferensial atau perlakuan yang masuk ke dalam model terlebih dahulu (Santoso, 2004).

Hasil pengolahan data terkait gaya belajar, capain mata kuliah Kalkulus Diferesial, dan IPK mahasiswa calon guru matematika dengan Ancova ditunjukkan oleh Tabel 3.

Tabel 3. Hasil Uji Ancova untuk Melihat Pengaruh Gaya Belajar, Capaian Mata Kuliah Kalkulus Diferensial, dan IPK Mahasiswa Calon Guru Matemarika

\begin{tabular}{lllllll}
\hline Source & $\begin{array}{l}\text { Type III Sum } \\
\text { of Squares }\end{array}$ & Df & $\begin{array}{l}\text { Mean } \\
\text { Square }\end{array}$ & F & Sig. & $\begin{array}{l}\text { Partial Eta } \\
\text { Squared }\end{array}$ \\
\hline Corrected Model & $7,064^{a}$ & 3 & 2,355 & 48,287 &, 000 &, 557 \\
Intercept & 15,713 & 1 & 15,713 & 322,222 &, 000 &, 737 \\
$\begin{array}{l}\text { Capaian MK Kal. } \\
\text { Diferensial }\end{array}$ & 6,433 & 1 & 6,433 & 131,924 &, 000 &, 534 \\
$\begin{array}{l}\text { Tipe Gaya Belajar } \\
\text { Error }\end{array}$ &, 307 & 2 &, 153 & 3,147 &, 047 &, 052 \\
Total & 5,608 & 115 &, 049 & & & \\
\hline Corrected Total & 1399,487 & 119 & & & &
\end{tabular}

Langkah pertama yang akan dilakukan adalah memeriksa asumsi penggunaan Ancova. Tabel 3 menunjukkan nilai signifikansi untuk peubah Capaian MK Kalkulus Diferensial adalah 0,000 dan nilai ini kurang dari 0,05, maka hipotesis yang menyatakan terdapat hubungan linier antara capaian MK Kalkulus Difrensial dengan IPK mahasiswa diterima, hal ini berarti bahwa pada tingkat kepercayaan 95\% dapat dikatakan bahwa terdapat hubungan linier antara covariate capaian MK Kalkulus Diferensial dengan variabel terikat IPK mahasiswa calon guru matematika. Pernyataan ini mengindikasikan bahwa asumsi penggunaan Ancova telah terpenuhi. Pengujian ini dilakukan dengan menghilangkan pengaruh perbedaan gaya belajar dari model terlebih dahulu.

Untuk mengetahui adanya pengaruh perbedaan gaya belajar terhadap IPK mahasiswa, dilakukan pengujian dengan menghilangkan pengaruh capaian MK Kalkulus Diferensial dari model terlebih dahulu. Dari Tabel 3 terlihat bahwa nilai signifikansi untuk variabel gaya belajar adalah 0,047. Karena nilai signifikansi kurang dari 0,05 maka hipotesis penelitian yang menyatakan bahwa terdapat pengaruh perbedaan gaya belajar terhadap IPK mahasiswa calon guru matematika diterima. Hasil ini mengindikasikan bahwa pada tingkat kepercayaan 95\% dapat disimpulkan bahwa terdapat pengaruh perbedaan gaya belajar terhadap IPK mahasiswa calon guru matematika. 
Selanjutnya, untuk mengetahui pengaruh perbedaan gaya belajar dan capaian MK Kalkulus Diferensial terhadap IPK mahasiswa secara simultan dapat dilihat dari nilai signifikansi pada bagian Corrected Model. Tabel 3 menunjukkan nilai signifikansi untuk baris "Corrected Model" adalah sebesar 0,000, dan nilai ini kurang dari 0,05 maka hipotesis penelitian yang menyatakan bahwa terdapat pengaruh perbedaan gaya belajar dan capaian MK Kalkulus Diferensial secara simultan terhadap IPK mahasiswa calon guru matematika diterima. Sehingga dapat disimpulkan bahwa pada tingkat kepercayaan 95\% secara simultan perbedaan gaya belajar dan capaian MK Kalkulus Diferensial mahasiswa berpengaruh terhadap IPK mahasiswa.

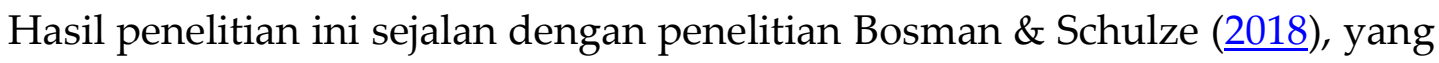
mengungkapkan bahwa gaya belajar individu berkorelasi tinggi dengan kinerja Matematika. Perbedaanya, yang menjadi fokus pada penelitian ini adalah capaian MK Kalkulus Diferensial dan IPK mahasiswa calon guru matematika, yang menggambarkan kemampuan yang diperoleh mahasiswa melalui internalisasi pengetahuan, keterampilan, dan sikap. Bosman \& Schulze (2018), merekomendasikan bahwa guru harus menciptakan lingkungan belajar yang positif di sekolah, dan menggunakan metode pengajaran yang mengakomodasi berbagai gaya belajar.

Untuk melihat berapa besar pengaruh variabel bebas dan covariate terhadap variable terikat, dapat dilihat dari Eta Square (effect size) pada tabel 3, yang dapat diartikan sebagai berikut: (a) IPK mahasiswa calon guru matematika secara simultan dipengaruhi oleh perbedaan gaya belajar dan capaian MK Kalkulus Diferensial sebesar 55,7\%; karena koefisien determinasi $\mathrm{R}^{2}$ sebesar 0.557, ini dapat diartikan juga bahwa variasi yang terjadi pada IPK mahasiswa calon guru matematika 55,7\% ditentukan oleh variasi yang terjadi pada perbedaan gaya belajar dan capaian MK Kalkulus Diferensial, (b) IPK mahasiswa calon guru matematika dipengaruhi oleh perbedaan gaya belajar sebesar 5,2\%, dan (c) IPK mahasiswa calon guru matematika dipengaruhi capaian MK Kalkulus diferensial sebesar 54,6\%.

Pengujian yang telah dilakukan dan didukung oleh data, menunjukkan bahwa terdapat pengaruh perbedaan gaya belajar terhadap IPK mahasiswa calon guru matematika. Capaian MK Kalkulus Diferensial merupakan salah satu komponen pembentuk IPK Mahasiswa calon guru matematika, telah ditunjukkan secara bersama-sama dengan perbedaan gaya belajar memiliki pengaruh terhadap IPK mahasiswa calon guru matematika. Secara parsial telah ditunjukkan capaian MK Kalkulus Diferensial memiliki pengaruh lebih 
besar dibandingkan dengan perbedaan gaya belajar terhadap IPK mahasiswa calon guru matematika.

Hasil ini sejalan dengan penelitian lain yang menyimpulkan, terdapat korelasi antara gaya belajar dengan capaian pembelajaran, termasuk diantaranya pemahaman konsep matematika (Gholani \& Bagheri, 2013; Magdalena, 2015; Liberna, 2018; dan Bosman \& Schulze, 2018). Capaian pembelajaran dalam penelitian ini di nyatakan dengan capaian IPK mahasiswa calon guru matematika. Ditemukan bukti bahwa pengaruh covariate nilai MK Kalkulus Diferensial lebih besar daripada pengaruh gaya belajar, hal ini memberi bukti bahwa selain gaya belajar terdapat faktor lain yang berpengaruh terhadap capaian IPK mahasiswa. Hal ini sejalan dengan rekomendasi hasil penelitian Magdalena (2015) dan Sabri, Safee, \& Wan Afthanorhan (2014) bahwa seorang guru harus mempertimbangkan faktor-faktor lain selain gaya belajar. Lingkungan belajar yang berfokus pada perbedaan individu juga perlu diciptakan, intervensi guru yang didasarkan atas preferensi gaya belajar siswa menawarkan pendekatan yang lebih baik dan berdasarkan bukti dapat meningkatkan hasil belajar (Can, 2009; Landrum, Landrum, \& Styles, 2016).

\section{Simpulan}

Secara simultan variabel bebas gaya belajar dan covariate nilai MK Kalkulus Diferensial memiliki pengaruh terhadap IPK mahasiswa calon guru matematika, sementara secara parsial nilai MK Kalkulus Diferensial memiliki pengaruh lebih besar dibandingkan dengan gaya belajar. Ini mengindikasikan bahwa MK Kalkulus Diferensial memiliki pengaruh yang cukup besar terhadap capaian pembelajaran mahasiswa, artinya dalam pelaksanaan perkuliahan mata kuliah ini harus menjadi perhatian baik dari mahasiswa, dosen pengampu, maupun program studi penghasil calon guru matematika. Mayoritas calon guru matematika memiliki modalitas gaya belajar auditory, di mana berdasarkan karakteristiknya mereka lebih mudah belajar dengan cara mendengar. Walaupun sumbangan gaya belajar terhadap IPK cukup kecil tidak berarti ini harus diabaikan, pembelajaran yang disesuaikan dengan karakteristik gaya belajar mahasiswa akan membuat situasi lebih kondusif, dengan harapan mahasiswa dapat mengembangkan potensinya. Perlu dikaji lebih lanjut karakteristik pembelajaran yang memperhatikan gaya belajar mahasiswa, perlu dirancang berbagai hal terkait pembelajaran yang dapat mengatasi berbagai permasalahan dalam Kalkulus Diferensial misalnya dari rancangan desain pembelajaraan, model pembelajran atau lainnya, juga perlu dikaji faktor-faktor lain yang dapat meningkatkan capaian pembelajaran mahasiswa calon guru matematika. 


\section{Daftar Pustaka}

Altun, H., \& Serin, O. (2019). Determination of learning styles and achievements of talented students in the fields of Science and Mathematics. Cypriot Journal of Educabertional Sciences, 14(1), 80-89. https://doi.org/10.18844/cjes.v14i1.3441

Aslaksen K., \& Lorås, H. (2019). Matching instruction with modality-specific learning style: Effects on immediate recall and working memory performance. Education Sciences, 9(1), 1-12. https://doi.org/10.3390/educsci9010032

Bosman, A., \& Schulze, S. (2018). Learning style preferences and mathematics achievement of secondary school learners. South African Journal of Education, 38(1), 1-8. https://doi.org/10.15700/saje.v38n1a1440

Can, Ş. (2009). The effects of science student teachers' academic achievements, their grade levels, gender and type of education they are exposed to on their 4mat learning styles (Case of Muğla University, Turkey). Procedia - Social and Behavioral Sciences, 1(1), 18531857. https://doi.org/10.1016/j.sbspro.2009.01.327

Constantinidou, F., \& Baker, S. (2002). Stimulus modality and verbal learning performance in normal aging. Brain and Language, 82(3), 296-311. https://doi.org/10.1016/S0093934X(02)00018-4

Dandy, K., \& Bendersky, K. (2014). Student and faculty beliefs about learning in higher education: Implications for teaching. International Journal of Teaching and Learning in Higher Education, 26(3), 358-380.

DePorter, B., \& Hernacki, M. (2007). Quantum Learning: Membiasakan Belajar Nyaman dan Menyenangkan (Alwiyah Abdurrahman, Penerjemah). Bandung: Kaifa.

Faculty, N. E. (2016). The Effect of the Match between the Learning and Teaching Styles of Secondary School Mathematics Teachers on Students' Achievement. Journal of Education and Practice, 7(29), 125-132. https://doi.org/10.7176/jep/7-29-4

Gholami, S., \& Bagheri, M. S. (2013). Relationship between VAK Learning Styles and Problem Solving Styles regarding Gender and Students' Fields of Study. Journal of Language Teaching and Research, 4(4), 700-706. https://doi.org/10.4304/jltr.4.4.700-706

Goulding, J., \& Syed-Khuzzan, S. (2014). A study on the validity of a four-variant diagnostic learning styles questionnaire. Education and Training, 56(2), 141-164. https://doi.org/10.1108/ET-11-2012-0109

Kim, D. J., Kang, H., \& Lee, H. J. (2015). Two different epistemologies about limit concepts. International Education Studies, 8(3), 138-145. https://doi.org/10.5539/ies.v8n3p138

Kolb, D. A. (1984). Experiential Learning: Experience as The Source of Learning and Development. Prentice Hall, Inc., 1984, 20-38. https://doi.org/10.1016/B978-0-7506-72238.50017-4

Landrum, T. J., Landrum, K., \& Styles, L. (2016). Learning Style, Learning Preferences, and Student Choice: Implications for Teaching. iii. https://doi.org/10.1108/s0735-004×20160000029016

Liberna, H. (2018). Hubungan Gaya Belajar Visual dan Kecemasan Diri Terhadap Pemahaman Konsep Matematika Siswa Kelas X SMK Negeri 41 Jakarta. JNPM (Jurnal Nasional Pendidikan Matematika), 2(1), 98-108. https://doi.org/10.33603/jnpm.v2i1.988

Magdalena, S. M. (2015). The Relationship of Learning Styles, Learning Behaviour and Learning Outcomes at the Romanian Students. Procedia - Social and Behavioral Sciences, 180(November 2014), 1667-1672. https://doi.org/10.1016/j.sbspro.2015.05.062

Montgomery, D. C. (2012). Design and Analysis of Experiments Eighth Edition. New York: John Willey \& Son.

Morgan, L. (1995). Learning Styles in the Classroom. In Training.

Newton, P. M., \& Miah, M. (2017). Evidence-based higher education - Is the learning styles 
"myth" important? Frontiers in Psychology, 8(MAR), 1-9. https://doi.org/10.3389/fpsyg.2017.00444

Orhun, N. (2012). The Relationship Between Learning Styles and Achievement in Calculus Course for Engineering Students. Procedia - Social and Behavioral Sciences, 47, 638-642. https://doi.org/10.1016/j.sbspro.2012.06.710

Orton, A. (1983).Students' Understanding of Differentiation Abstract . A clinical interviewing method was used to investigate students ' understand-ing of elementary calculus. The analysis of responses to tasks concerned with differenti-ation and rate of. 14, 235-236.

Pritchard, A. (2009). Ways of Learning. In The Lancet (1st ed., Vol. 246, Issue 6365). Routledge, 2 Park Square, Milton Park, Abingdon, Oxon )X14 4RN. https://doi.org/10.1016/S01406736(45)91319-5

Rourke, B. P., Ahmad, S. A., Collins, D. W., \& Warriner, E. M. (2002). Child Clinical / Pediatric Neuropsychology: Some Recent Advances. https://doi.org/10.1146/annurev.psych.53.100901.135204

Sabri, A., Safee, S., \& Wan Afthanorhan, W. M. A. (2014). Learning styles towards mathematics achievements among higher education students. Global Journal of Mathematical Analysis, 2(2), 50-52. https://doi.org/10.14419/gjma.v2i2.2267

Santoso, S. (2004). Buku Latihan SPSS Statistik Multivariat. Elex Media Komputindo.

Sirmaci, N. (2010). The relationship between the attitudes towards mathematics and learning styles. Procedia - Social and Behavioral Sciences, 9, 644-648. https://doi.org/10.1016/j.sbspro.2010.12.211

Tonra, W. S., Budiarto, M. T., Masriyah, \& Tonra, W. S. (2019). Profile of High Order Thingking Skill ( HOTS ) of Junior High School Students ' Grade 8 in Solving Linear Equation System Problems Based on Kinesthetic and Visual Learning Styles. International Journal of Trends in Mathematics Education Research, 2(4), 212-214. https://doi.org/10.33122/ijtmer.v2i4.139

Wahyuni, A. (2017). Analisis Hambatan Belajar Mahasiswa Pada Mata Kuliah Kalkulus Dasar. JNPM (Jurnal Nasional Pendidikan Matematika), 1(1), 10-23. https://doi.org/10.33603/jnpm.v1i1.253

Yildirim, O., Acar, A. C., Bull, S., \& Sevinc, L. (2008). Relationships between teachers' perceived leadership style, students' learning style, and academic achievement: A study on high school students. Educational Psychology, 28(1), 73-81. https://doi.org/10.1080/01443410701417945 